\title{
Off to School: Filmic False Equivalence and Indian Residential School Scholarship
}

\author{
Jane Griffith
}

Ryerson University

\begin{abstract}
This paper uses two short, mid-twentieth century documentaries produced by the National Film Board of Canada as an entry point into charting popular and scholarly representations of Indian residential schools. The article begins with a close reading of one 1958 film followed by an overview of how scholarship has changed over the last fifty years, particularly alongside and sometimes because of the Truth and Reconciliation Commission of Canada. The article advocates centring survivor testimony and provides major turns in considering as well as teaching about residential schooling and settler colonialism in Canada. The article concludes with a close reading of a second film, produced in 1971 by Abenaki filmmaker Alanis Obomsawin, which offers a decidedly different perspective from the film discussed at the beginning of the article.
\end{abstract}

RÉSUMÉ

Cet article utilise deux courts documentaires produits par l'Office national du film à l'époque du centenaire de la Confédération comme point de départ permettant d'étudier les représentations populaires et universitaires des pensionnats indiens. L'article s'amorce sur une lecture attentive d'un film de 1958, puis propose un aperçu des changements survenus dans la littérature académique au cours des cinquante dernières années, en particulier grâce à la Commission de vérité et réconciliation du Canada. Il met l'accent sur le témoignage des survivants et propose des changements importants, à la fois dans la façon de comprendre le système des pensionnats et le colonialisme canadien, de même que sur les façons de l'enseigner et les leçons à en tirer. L'article se termine par l'analyse d'un second film produit en 1971par la cinéaste Abénaquis Alanis Obomsawin, qui offre une perspective très différente de celui tourné en 1958.

In 1958, the National Film Board of Canada (NFB) produced an eight-minute documentary about schools located far from the homes of their students. The NFB film is divided into three parts: the first depicts children from Pender Island, British Columbia, who take a ferry to school each day. ${ }^{1}$ The second part portrays an educational railway train that visits students in remote Ontario communities. The final part of the film focuses not on transportation that enables settler children to receive 
a public education but on an Indian residential school.

Such schools, referred to by several names over their nearly 150 -year existence, were jointly operated by the Canadian government and various churches. Their origins extend back to the seventeenth century, and the last one closed in 1996. Residential schools were places to both house and teach Indigenous children who were removed, often without parental consent and by force, from their homes. As the testimony and memoirs of survivors and their families - the only experts on the experiences of residential schooling - reveal, family visits and communication were typically restricted. Indigenous children went for prolonged periods immersed in environments that asserted the supremacy of whiteness, Christianity, the English language, heteronormativity, patriarchy, and European understandings of land. And while some former students recall positive moments, these were often in spite of the fact that residential schools were also sites of crimes and abuse. The activities of the Truth and Reconciliation Commission of Canada (TRC) concluded in 2015, resulting in a multi-volume final report and ninety-four Calls to Action based on testimony it gathered and archival research it conducted into residential schools. It is the only such inquiry in the world to investigate crimes perpetrated exclusively against children, for such a long period, and within a country not transitioning from a dictatorship. The commission was not a gift from a newly remorseful state but instead resulted from mounting pressure and legal proceedings against the government by survivors.

The third part of the film Off to School features an Anglican-run residential school in Moose Factory, Ontario. The clip begins with fingers on a map, anticipating NFB viewers who might require colonial lines of cartography to locate this school, unlike the locations of the first two narratives. The clip shows students learning calisthenics, playing hockey, and repairing motors. The disembodied voice-over mocks Indigenous children's names. The camera cuts to a portrait of the queen and a spelling list - vocabulary such as "purchase," "desire," "wealthy," and "grateful" suggest a curriculum concomitant with capitalism.

These vignettes, grouped together in Off to School as a single narrative, offer a false equivalence (see Figures 1-3). In the first two scenarios, the state is shown to have creatively ensured that students attended school, but not at the expense of returning home each night. In contrast, residential schools could hardly be deemed creative, particularly in 1958, after a system marked by failure was nearly 100 years old. ${ }^{2}$ The solutions of ferry and train accommodated the professions of the children's fathers, as these were stated in the film. The fathers participated in an extractive resource economy, working as fishermen, railway workers, loggers, and trappers; the film states that they were "men whose work takes them to places where there just aren't any regular schools." In these narratives, parents pack lunches and assist with homework, whereas children in residential schools - the voice-over explains matter-of-factly — "may be orphans. They may come from broken homes. Or they may be isolated in remote settlements." According to this explanation, parents are negligent or even non-existent; the film frames the state, in contrast, as a solution to a decontextualized and unnamed problem.

The ferry and the train are not unrelated to the residential schools. Colonial tactics such as residential schools contributed to the displacement of Indigenous 


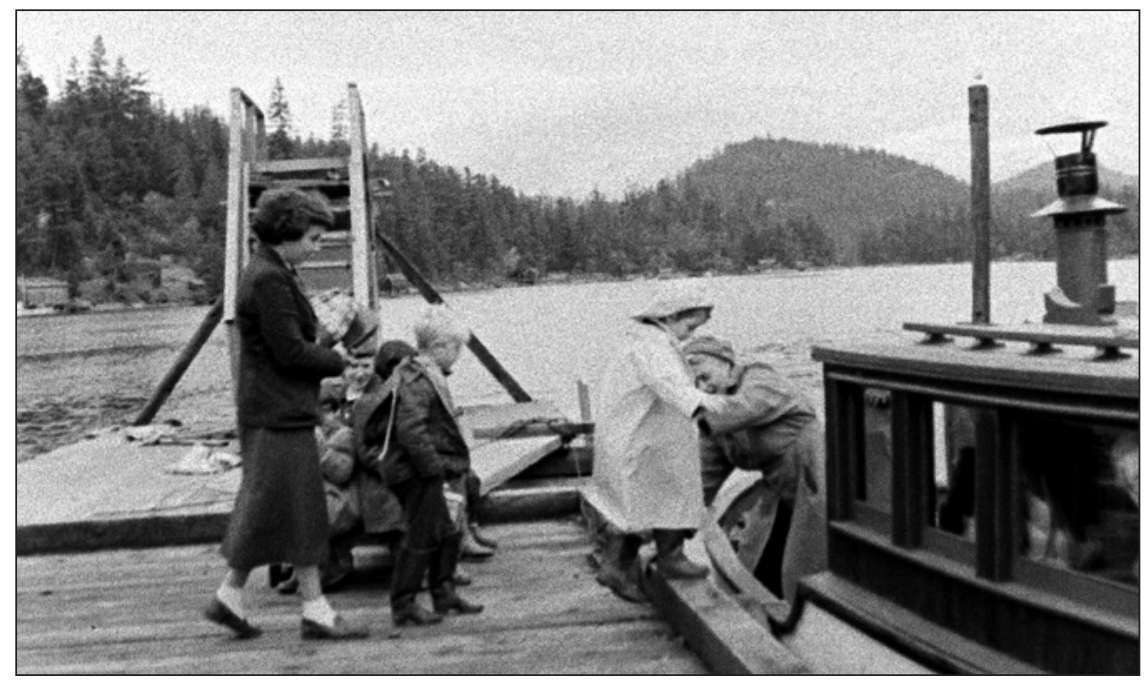

Figure 1. Off to School, 1958. National Film Board of Canada.

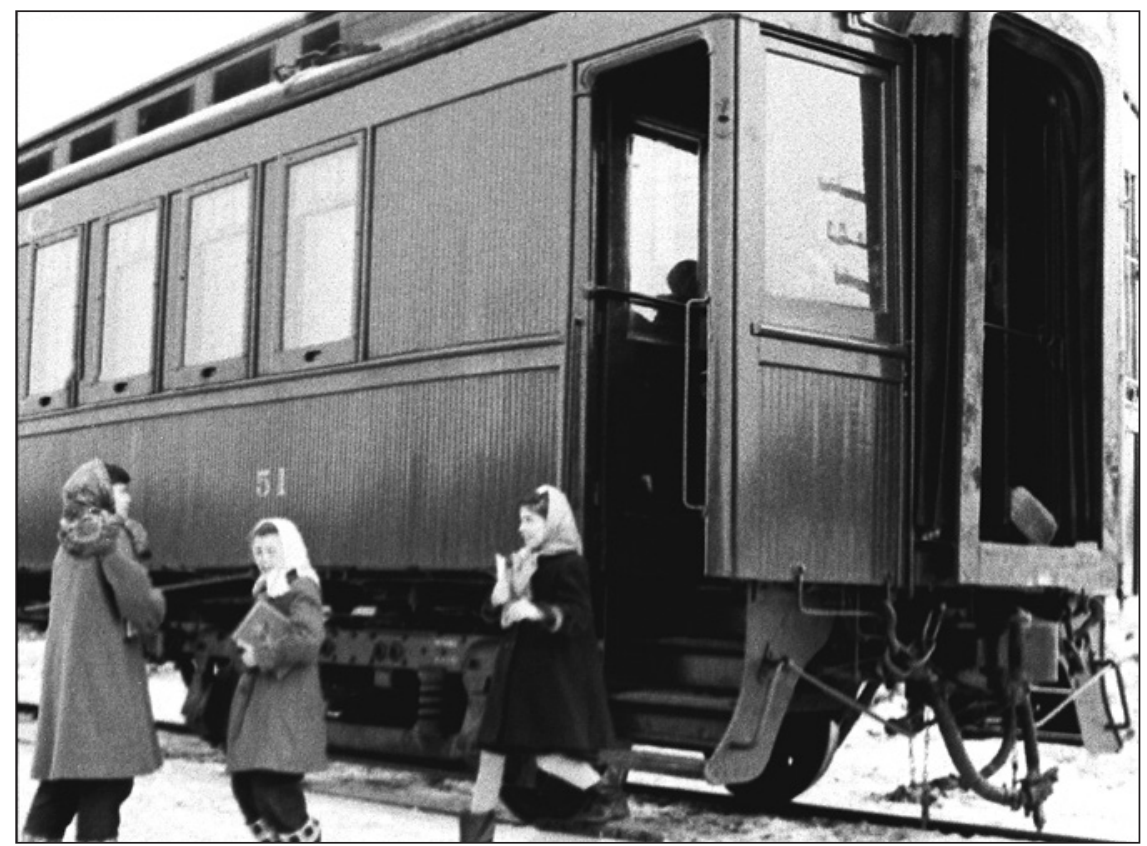

Figure 2. Off to School, 1958. National Film Board of Canada.

peoples, making it possible for settlers to claim land and profit from it. In settler colonies, the ultimate fantasy is that Indigenous peoples disappear, allowing settler colonizers to construct a narrative in which they, not Indigenous peoples, are the original, rightful inhabitants. On another level, residential schools also perpetuated 


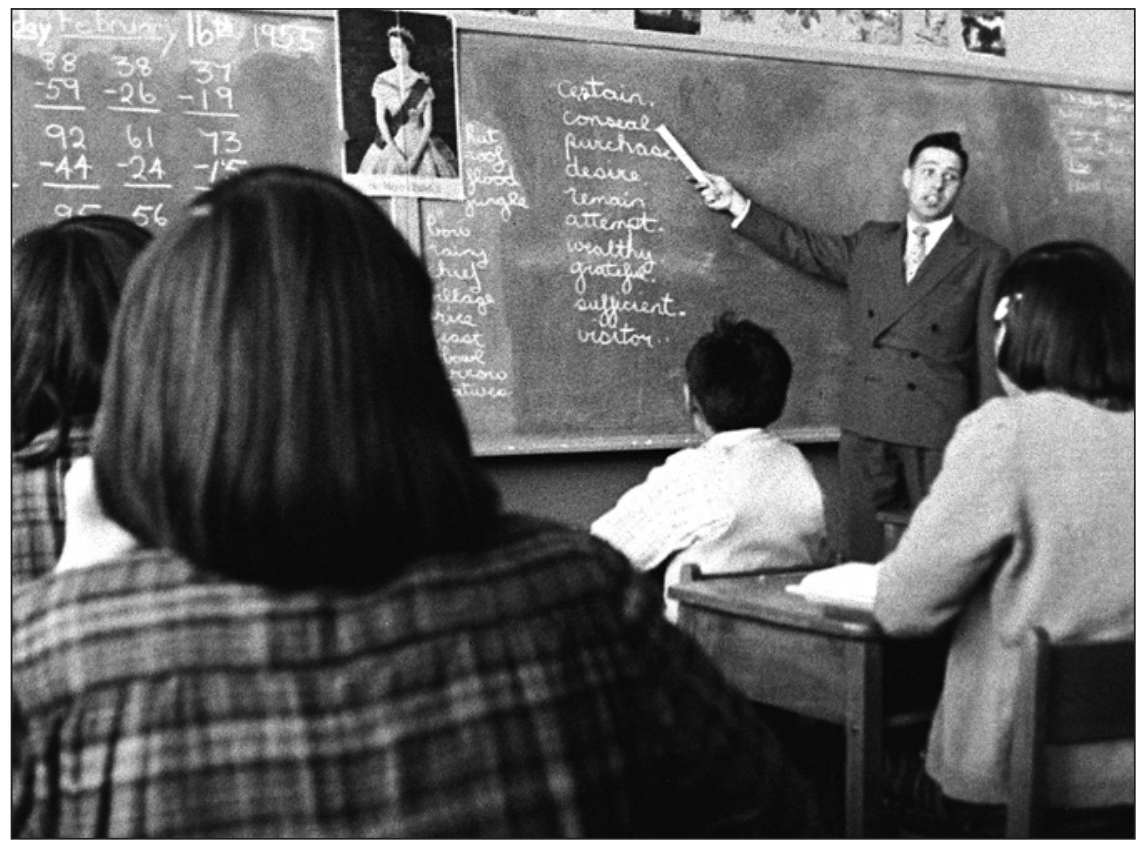

Figure 3. Off to School, 1958. National Film Board of Canada.

settler colonial goals through approaches that separated children from their languages, parents, extended families, communities, political structures, spiritualities, and ceremonies - further ties to land. Off to School groups together these three scenarios, but not to feature their larger colonial links. Rather, their superficial similarities of education and distance mute these connections: two narratives depict the benefits of settler colonialism for settlers, and one denies the violence of settler colonialism directed at Indigenous peoples. Settler denial was not left back in 1958, but instead persists today. ${ }^{3}$

Viewing Off to School now, post-TRC (but not post-truth or post-reconciliation), opens up much for contemplation about the many changes and continuities concerning schooling and colonialism since 1958.

\section{Scholarly Perspectives}

Two historical monographs on the overall Indian residential school system loom large: J. R. Miller's Shingwauk's Vision (1996) and John Milloy's A National Crime (1999). Milloy's book was recently reissued in a new edition, with a foreword by Mary Jane Logan McCallum that offers an extensive historiography of residential schooling. ${ }^{4}$ Miller's and Milloy's studies, both first printed in the 1990s, have since been joined by volume 1 of the TRC's six-volume final report: the history of residential schools from their origins to 1939 (Part 1) and from 1939 to 2000 (Part 2). ${ }^{5}$ Brian Titley's work has zeroed in on particular commissioners and policy-makers responsible for 
Indian affairs. ${ }^{6}$ Miller, Milloy, Titley, and the historical volume of the final report paint a comprehensive picture of the policies, administrators, and laws that shaped residential schools; McCallum's foreword contextualizes such scholarship.

Miller describes the pre-Confederation origins of the schools. In the seventeenth century, European-run schools in North America for Indigenous children emphasized conversion to Christianity first and assimilation second. ${ }^{7}$ After 1812, Indigenous peoples were viewed less as sovereign allies and more as wards, and the evolving policies on schooling later in the nineteenth century reflected this change. The Bagot Commission of 1842 concluded that little progress had been made in the previous ten years to "civilize" Indigenous peoples, so in 1846 the superintendent of Indian Affairs met with chiefs and missionaries at a conference in Orillia to pitch manual labour schools as the answer. ${ }^{8}$ In 1847, Egerton Ryerson, the chief superintendent of education for Upper Canada, fleshed out what these schools might look like. Despite advocating for secular education in the Common School Act the year before for non-Indigenous children, Ryerson believed that "the North American Indian cannot be civilized or preserved in a state of civilization (including habits of industry and sobriety) except in connection with, if not by the influence of, not only religious instruction and sentiment but of religious feelings." In 1868, the state began funding two residential and many non-residential schools attended by Indigenous students. Another consultation on Indian boarding school policy that historical research focuses on is the 1879 Report on Industrial Schools for Indians and Half-Breeds (the Davin Report), which offered lessons on schools in the U.S. with applicability for Canada and advised the growth of residential schools over day schools.

Both Miller and Milloy further focus on how a new per capita system instituted in 1892 proved to be a disastrous funding model, forcing schools to now recruit and retain children who would previously not be accepted (for example, those who were sick) to keep numbers high. The new funding model also put pressure on schools to serve even unhealthier food and to require more student labour, leading to higher death rates. ${ }^{10}$ This per capita model was an ineffective attempt at patching up earlier funding problems within schools. As Milloy notes, schools grew rapidly at this time because of missionary pressures but also state acquiescence to such pressures. According to Sean Carleton's recent research on nascent colonial schooling in the Pacific Northwest, the state supported missionary schools not to support the spread of Christianity but because the missionaries served as buffers - "part of a strategy of trying to check the power of Indigenous peoples to strengthen colonial security and bolster British control."11 These historical sources also chart the changes in compulsory attendance, chronic government underfunding, and abuse allegations that were denied and ignored. This research focuses on overarching systems, policies, and complicity.

Alongside these archival-based studies exists qualitative research, such as the work of Celia Haig-Brown, Elizabeth Furniss, and Agnes Jack. ${ }^{12}$ This work typically focuses on the memories of many former students from one school. These interviews reveal both the overlapping and individual experiences of students at the school and after, as well as the ability for students to not only survive but also to resist the assimilationist 
goals of the school. Qualitative research often focuses not on victimhood and pity but on resistance - a move away from what Eve Tuck calls damage-centred research. ${ }^{13}$

New directions in research on residential schools feature different geographical analyses and new parameters for defining colonial education. In terms of geography, new studies include comparisons between Canada and other settler colonial states. ${ }^{14}$ Such studies consider how, particularly between the U.S. and Canada, there was actually consultation across the colonial border despite the earlier tendency of researchers to examine Indian boarding schools in either Canada or the U.S. ${ }^{15}$ For instance, Michael Marker discusses Coast Salish youth who attended schools in both Canada and the U.S. amidst widely different school policies and histories across the colonial border. ${ }^{16}$ New research also includes the investigation of Indian day schools, such as in the work of Helen Raptis, which were largely excluded from consideration by the TRC but likewise incorporated assimilative educational goals. ${ }^{17}$ Other studies, such as those conducted by Ian Mosby, have focused on archival research and individuals' testimony to learn more about experiments conducted on children in Indian residential schools and about student health before and after attending these schools. ${ }^{18}$ New research is also emerging on the distinct histories of residential schooling in the North. Such schools were established much later than residential schools elsewhere in Canada, and the final TRC report includes an entire volume titled The Inuit and Northern Experience to begin unpacking these distinctions. ${ }^{19}$

In addition to these new directions, inquiries have included the role of literature and memoir in the learning and teaching about residential schooling. Unlike the focus on residential school systems or an individual school, such texts offer insights into the experiences of individual students. And more than this, Jo-Ann Episkenew writes that Indigenous autobiography, including the memoirs of residential school survivors, offers "eyewitness testimony to historical injustices." ${ }^{20}$ Fiction, drama, poetry, and children's literature about residential schools by survivors and their families generally appeared later, followed by scholarship on how to teach with these texts. ${ }^{21}$ Sam McKegney highlights how residential school literature provides "the Indigenous author interpretive autonomy and discursive agency while transcending the structural imperatives of proof and evidence embedded in historical paradigms." 22

Some of the earliest printed accounts of residential schools include survivor memoirs, such as Basil Johnston's 1989 book, Indian School Days. ${ }^{23}$ Scenes of constant hunger, escape attempts, inept teachers, and servitude at Spanish Indian Residential School in northern Ontario undergird its lighthearted moments, which in 2007 Johnston qualified by disclosing the sexual abuse he faced there. ${ }^{24}$ Isabelle Knockwood's Out of the Depths (1992), about her time at Shubenacadie Indian Residential School in Nova Scotia, is more explicit about the physical, emotional, and sexual abuse she and her classmates endured. ${ }^{25}$ More survivor accounts have been published during and after the TRC hearings — pieces by Theodore Fontaine, Bev Sellars, Edmund Metatawabin, Augie Merasty, and Arthur Bear Chief. ${ }^{26}$ Such richly detailed testimony contextualizes what life was like before, during, and after time was spent in these institutions. Most importantly, these are published accounts that survivors wished for varied audiences to encounter, unlike stories and testimony that were 
told in confidence. ${ }^{27}$ This tension between evidence of residential schooling meant for public versus private audiences came to a head during the TRC hearings after some survivors wished for their testimony to be destroyed while the commission held the position that "the loss of these documents would be a blow to Canada's national memory of a significant historic injustice. ${ }^{28}$ Recent scholarship insists that listening to testimony of any kind requires instruction on how not to appropriate, voyeuristically consume, or passively listen to a survivor's experiences, but instead on how to bear witness. ${ }^{29}$ Such contexts are helpful when considering first-person accounts of residential schools as well as the complicated contours of proof and evidence.

There has also been recent research on the TRC itself. While research on state apologies and truth commissions more generally helps to contextualize the current national discussions on Indian residential schools, other scholars identify state apologies and commissions for crimes against Indigenous peoples specifically. ${ }^{30}$ Texts such as Truth and Indignation (2013) and Unsettling the Settler Within (2010) have probed the possibilities and pitfalls of Canada's TRC, critical of the immense onus on Indigenous peoples with little responsibility required from non-Indigenous Canadians. ${ }^{31}$

New theoretical understandings of residential schooling include settler colonial analyses. Patrick Wolfe is often credited with the term "settler colonialism," although, of course, Indigenous peoples have understood the concept and fought it for centuries. ${ }^{32}$ Wolfe and others distinguish settler colonialism from colonialism, which requires some colonizers on the ground but mostly depends on the labour of those Indigenous to the land. ${ }^{33}$ The primary goal of colonialism is not for high numbers of colonizers to remain in a territory and consider it their own. Settler colonialism, in contrast, never completely depends on Indigenous labour — just land. A key tenet of settler colonialism is a denial of violence, wherein the state "appropriates the identity of marginalization and victimization to create national innocence." ${ }^{34}$ As Wolfe observes, settler colonialism is a structure, not an event: it is ongoing. Such analyses have influenced more recent studies on residential school history, centring education as one of many colonial strategies for acquiring land. The limitations of settler colonial studies have also been observed. Corey Snelgrove, Rita Kaur Dhamoon, and Jeff Corntassel, for instance, warn how settler colonial studies as well as solidarity initiatives have the potential to replicate colonial methods of domination, and Eve Tuck and K. Wayne Yang argue that decolonization is not a metaphor - for them, decolonization means a return of land. ${ }^{35}$

Andrew Woolford's concept of settler colonialism as layers of nets - which can constrain but also have holes - is helpful. Woolford describes one layer of netting as the widest, representing institutions such as the economy, education, government, and religion. The middle net is a stand-in for state-sponsored agencies such as the military, police, law, health, and welfare. The third level of nets includes parents, children, teachers, principals, and communities. For Woolford, all three layers of net create a mesh, and understanding any specific residential school experience requires thinking of all three levels. In some places, the mesh tightens; in other places, it loosens. Loosening and tightening happens differently across time and space, "but the 
genocidal frame of reference remains" - even with a nice teacher. ${ }^{36}$ Recent research on residential schools is also more likely to name such institutions as genocidal, while research from the 1990 s typically did not. ${ }^{37}$

A future change in both public discourse as well as scholarship may include understanding residential schooling not, as Stephen Harper said in his apology, as a "dark chapter," an isolated, anomalous aberration — but as one colonial tactic among many, from ongoing land dispossession, to the prison-industrial complex, and environmental racism. The TRC's Calls to Action further name multiple institutions in addition to residential schools, such as prisons, the child welfare system, the justice system, and health care services.

This special issue considers histories of education that are known today but were not fifty years ago. What may be helpful is to separate out histories that are now known to scholars half a century later due to new evidence or methodologies and those histories instead that settlers did not want to know or acknowledge. During Canada's centennial celebrations, for instance, Indigenous peoples mounted the Indians of Canada Pavilion at Expo '67 in Montreal among flagrant celebrations of settler colonialism. ${ }^{38}$ In this pavilion, pointed critiques by Indigenous peoples of colonial education were loud and clear.

\section{Filmic False Equivalence}

Famed Abenaki filmmaker Alanis Obomsawin began her career in 1971 with a short NFB documentary titled Christmas at Moose Factory - a very different film from the one with which I began this paper. ${ }^{39}$ Obomsawin's film was originally recorded in 1967, almost ten years after Off to School. By the time her film was made, the former residential school dubbed as "flourishing [and] modern" in Off to School now operated only as a hostel for students attending a local school. The two films bookend the many changes to residential schools at this time. Whereas 60 per cent of school-aged Indigenous children in 1948 went to residential school, 60 per cent of the same demographic in 1969 were taught in integrated provincial schools - a dramatic change largely fueled by financial considerations. ${ }^{40}$ The time between the two films was punctuated by reform efforts, including the Caldwell Report (1967), amidst Indigenous resistance. The government's co-running of residential schools with churches officially ended in 1969 , replaced by contracts signed with the provinces. ${ }^{41}$ The year after Obomsawin's film came out, the 1972 report, Indian Control of Indian Education, appeared, written by members of the National Indian Brotherhood. It espoused the need for parental control over education, culturally relevant curriculum, support for Indigenous teachers, and improved facilities. ${ }^{42}$ The time that had passed between the two films also included great changes in the ways children were portrayed on screen, particularly by the NFB. ${ }^{43}$

Christmas at Moose Factory opens with Cree syllabics. Unlike Off to School, Obomsawin begins her film locating Moose Factory for viewers not with a hand indicating a map of provincial borders but instead describing the area's tidal flats and lowlands, illustrated by children's art. Off to School only mentions the homes 


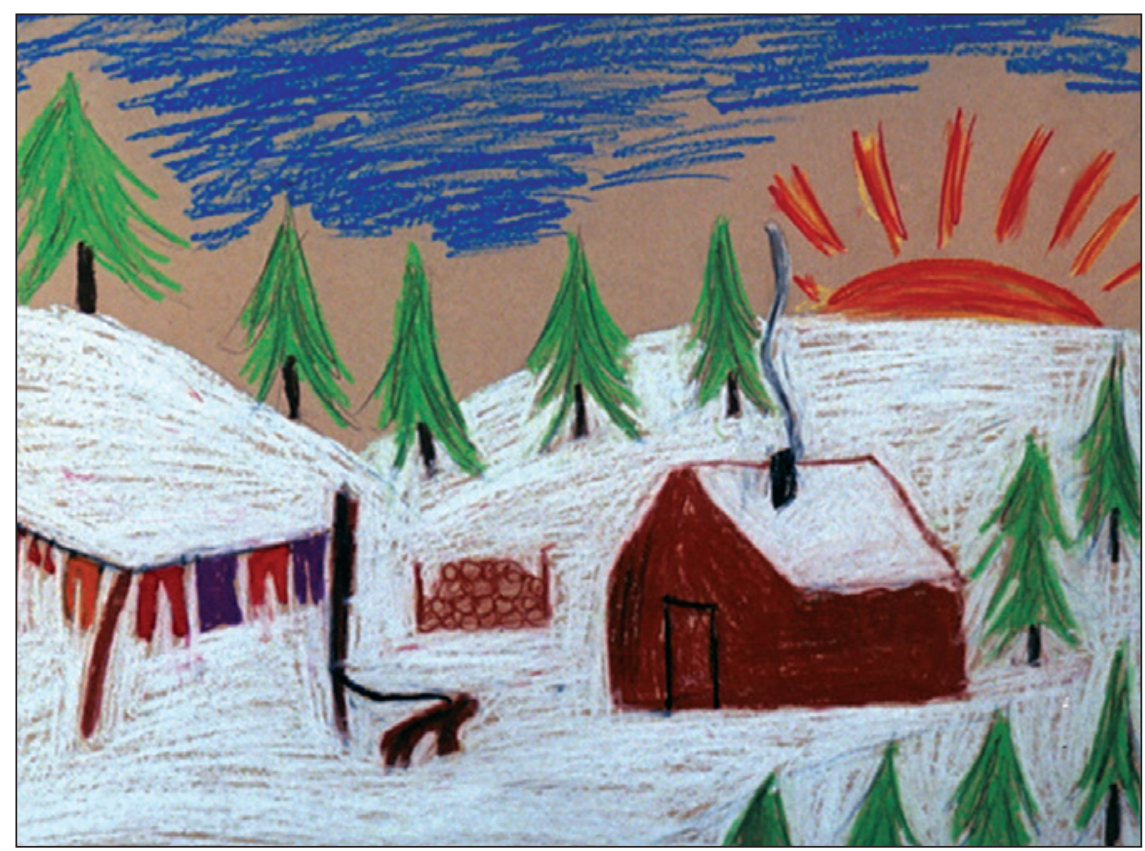

Figure 4. Christmas at Moose Factory, directed by Alanis Obomsawin, 1971. National Film Board of Canada.

and parents of Indigenous children to note they are broken, while in Christmas at Moose Factory children themselves narrate warm stories of home life (see Figure 4). Some children describe an "Indian angel" in their drawings, while in another scene, students sing in Cree. Students move among various topics and stories in their art compared to the structured calisthenics and scripted demonstrations of love at a Valentine's Day party in Off to School. Obomsawin ends with photographs of children and lists their names, which in Off to School are only mentioned for comic relief.

Obomsawin's film is not just a more sympathetic version of the earlier NFB film: the film extends a humanity to the children not present in Off to School. Obomsawin's film permits the voices of students who warmly discuss their parents, never portrayed here as broken or as undeserving of their own children. What is more, Obomsawin offers this space for Indigenous children as individuals, a history of education deserving of its own contemplation whereas Off to School attempts to flatten distinctions between education for settlers and education for Indigenous children.

Christmas at Moose Factory was the beginning of Obomsawin's career. Fifty years later, Obomsawin has created forty-nine films often critical of Canada, with a particular focus on education and young people. Just one example, Obomsawin's recent film, Hi-Ho Mistahey!', probes the deeper story of students forced off reserve to attend high school. While Christmas at Moose Factory may not appear as critical compared 
to her later work, it too reveals a way in which children's own voices were pushing against narratives about themselves, their parents, and their land.

In addition to Obomsawin and the NFB, many films on residential schools by Indigenous filmmakers make for important inclusions in any course syllabus: Christine Welsh's Kuper Island: Return to the Healing Circle, Terrance Houle's Cows, Lisa Jackson's Suckerfish, Nadia McLaren's Muffins for Granny, Shelley Niro's Robert's Paintings, Keesic Douglas and Lena Recollet's Historical Landmark, Shane Belcourt's A Common Experience, Jeff Barnaby's Rhymes for Young Ghouls, and Kent Monkman's Sisters \& Brothers are a small sampling of the many films that offer new and varied glimpses that complement survivor testimonies. ${ }^{44}$

\section{Conclusion}

What are the implications for new understandings of the past in shaping the future of education? Recent scholarship as well as these films about the residential school system have offered new questions for considering colonial histories and presentday realities - far more than the film Off to School permits. What institutions today continue the assimilative goals of residential schools? How are settlers co-opting narratives of reconciliation? What are films and fiction by Indigenous artists teaching about histories of colonial education? What can be done to implement the TRC's Calls to Action? What pedagogical work must be done to bear witness, rather than passively listen to, survivor testimony? What will happen now that the TRC has concluded? In 2017, the president of the Wildrose riding association likened residential schools to gay-straight alliances in high schools today because neither offered choices to parents; ${ }^{45}$ in 2016, a Saskatchewan MP in 2016 compared residential schools to Ontario's imposition of a sex education curriculum. ${ }^{46}$ These two post-TRC examples reveal a disturbing comfort in using residential school history for settler political gain as well as a continuity of false equivalence.

I write this as the NFB has just launched its Indigenous Action Plan, offering new supports for Indigenous-directed films, among other changes. ${ }^{47}$ Time will tell how such changes affect the NFB. Perhaps the plan will prompt what Dylan Robinson and Keavy Martin call "aesthetic action," which they define as "a range of sensory stimuli — image, sound, and movement — [that] have social and political effects through our affective engagements with them. In other words... the ways in which the TRC proceedings and artworks related to the Indian residential school system have impacts that are felt-whether this is through emotion or sensory experience - and to what degree these impacts result in change." ${ }^{48}$ The next question may be how aesthetic action can guard against false equivalence-filmic or otherwise - with a broader concern for further resistance to settler colonialism. With new research centres devoted to residential schools, museum displays, and curriculum, these are just some of the new directions for considering the history of schools and present-day settler colonialism. 


\section{Additional Readings}

Chrisjohn, Roland and Sherri Young. The Circle Game: Shadows and Substance in the Indian Residential School Experience in Canada. Penticton, BC: Theytus Books, 2006.

Final Report of the Truth and Reconciliation Commission of Canada, Volume 1, Part 1, Canada's Residential Schools: The History, Part 1, Origins to 1939, and Volume 1, Part 2, The History, Part 2, 1939 to 2000. See also Truth and Reconciliation Commission of Canada report, The Survivors Speak, available at the TRC website, trc.ca.

Fontaine, Theodore. Broken Circle: The Dark Legacy of Indian Residential Schools; A Memoir. Surrey, BC: Heritage House, 2010.

Knockwood, Isabelle. Out of the Depths: The Experiences of Mikmaw Children at the Indian Residential School at Shubenacadie, Nova Scotia. Fourth edition. Halifax: Fernwood, 2015 .

Metatawabin, Edmund with Alexandra Shimo. Up Ghost River: A Chief's Journey through the Turbulent Waters of Native History. Toronto: Vintage Canada, 2014.

Miller, J. R. Shingwauk's Vision: A History of Native Residential Schools. Toronto: University of Toronto Press, 1996.

Milloy, John S. A National Crime: The Canadian Government and the Residential School System, 1879 to 1986, 2nd edition. Winnipeg: University of Manitoba Press, 2017.

Raptis, Helen with members of the Tsimshian Nation. What We Learned: Two Generations Reflect on Tsimshian Education and the Day Schools. Vancouver: UBC Press, 2016.

Sellars, Bev. They Called Me Number One: Secrets and Survival at an Indian Residential School. Vancouver: Talonbooks, 2013.

Woolford, Andrew. This Benevolent Experiment: Indigenous Boarding Schools, Genocide, and Redress in Canada and the United States. Lincoln, NE: University of Nebraska Press, 2015.

\section{Notes}

1 See Sylvia Olsen with Rita Morris and Ann Sam, No Time to Say Goodbye: Children's Stories of Kuper Island Residential School (Winlaw, BC: Sono Nis, 2001) and Christine Welsh, Kuper Island: Return to the Healing Circle, Gumboot Productions, 1997, for more on a residential school near Pender Island. For more on residential schooling in British Columbia, see Jean Barman, "Schooled for Inequality: The Education of British Columbia Aboriginal Children," in Children, Teachers and Schools in the History of British Columbia, ed. Mona Gleason and Jean Barman (Edmonton: Brush, 2003), 55-80; and Sean Carleton, "Settler Anxiety and State Support for Missionary Schooling in Colonial British Columbia, 1849-1871," Historical Studies in Education 29, no. 1 (2017): 57-76.

2 John S. Milloy cautions that we cannot think of residential schools solely as beginning with the Davin Report of 1879; see A National Crime: The Canadian Government and the Residential School System, 1879 to 1986 (Winnipeg: University of Manitoba Press, 1999), 52. Still, many scholars point to the 1860s and 1870s as the beginning of the system in post-Confederation Canada, given that the state began partnering with church-run schools at that time. 
3 In 2017, Senator Lynn Beyak decried how "remarkable works, good deeds and historical tales in the residential schools go unacknowledged for the most part and are overshadowed by negative reports" - comments she made in front of fellow senator Murray Sinclair, one of the commissioners of the Truth and Reconciliation Commission. Lynn Beyak, "Increasing Over-Representation of Indigenous Women in Canadian Prisons," Orders of the Day (2017).

4 Mary Jane Logan McCallum, "Foreword," in John S. Milloy's A National Crime: The Canadian Government and the Residential School System, 1879 to 1986, second edition (Winnipeg: University of Manitoba Press, 2017).

5 Other volumes of the final report consider Inuit experiences, Métis experiences, missing children, and unmarked burials, legacies, and reconciliation.

6 E. Brian Titley, A Narrow Vision: Duncan Campbell Scott and the Administration of Indian Affairs in Canada (Vancouver: UBC Press, 1986); E. Brian Titley, The Indian Commissioners: Agents of the State and Indian Policy in Canada's Prairie West, 1873-1932 (Edmonton: University of Alberta Press, 2009); Brian Titley, The Frontier World of Edgar Dewdney (Vancouver: UBC Press, 2011).

7 J. R. Miller, Shingwauk's Vision: A History of Native Residential Schools (Toronto: University of Toronto Press, 1996), 451.

8 Milloy, A National Crime, 13; Miller, Shingwauk's Vision, 83.

9 "Report by Dr. Ryerson on Industrial Schools, Appendix A," in Statistics Respecting Indian Schools (Ottawa: Government Printing Bureau, 1847).

10 Miller, Shingwauk's Vision, 128-33; Milloy, A National Crime, 61-67.

11 Carleton, "Settler Anxiety and State Support for Missionary Schooling," 71-72.

12 See Celia Haig-Brown, Resistance and Renewal: Surviving the Indian Residential School (Vancouver: Tillacum Library, 1988); Elizabeth Mary Furniss, Victims of Benevolence: The Dark Legacy of the Williams Lake Indian Residential School (Vancouver: Arsenal Pulp Press, 1995); Agnes S. Jack, Behind Closed Doors: Stories from the Kamloops Indian Residential School (Kamloops, BC: Secwepemc Cultural Education Society, 2006). A further example from the U.S. includes K. Tsianina Lomawaima, They Called It Prairie Light: The Story of Chilocco Indian School (Lincoln, NE: University of Nebraska Press, 1995).

13 Eve Tuck, "Suspending Damage: A Letter to Communities," Harvard Educational Review 79, no. 3 (2009): 409-27.

14 Brenda J. Child and Brian Klopotek, eds., Indian Subjects: Hemispheric Perspectives on the History of Indigenous Education, Global Indigenous Politics Series (Santa Fe, NM: School for Advanced Research Press, 2014); Andrew Woolford, This Benevolent Experiment: Indigenous Boarding Schools, Genocide, and Redress in Canada and the United States (Lincoln, NE: University of Nebraska Press, 2015); Margaret D. Jacobs, "Indian Boarding Schools in Comparative Perspective," in Boarding School Blues: Revisiting American Indian Educational Experiences, ed. Clifford E. Trafzer, Jean A. Keller, and Lorene Sisquoc (Lincoln, NE: University of Nebraska Press, 2006), 202-31; Jane Griffith, "News from School: Language, Time, and Place in the Newspapers of 1890s Indian Boarding Schools in Canada" (PhD diss., York University, 2015).

15 See the following for studies on American Indian boarding schools: Amanda J. Cobb, Listening to Our Grandmothers' Stories: The Bloomfield Academy for Chickasaw Females, 1852-1949 (Lincoln, NE: University of Nebraska Press, 2000); Brenda J. Child, Boarding School Seasons: American Indian Families, 1900-1940 (Lincoln, NE: University of Nebraska Press, 1999); David Wallace Adams, Education for Extinction: American Indians and the Boarding School Experience, 1875-1928 (Lawrence, KS: University Press of Kansas, 1995); Lomawaima, They Called It Prairie Light.

16 Michael Marker, "Borders and the Borderless Coast Salish: Decolonising Historiographies of Indigenous Schooling," History of Education 44, no. 4 (2015): 480-502. 
17 Helen Raptis, with members of the Tsimshian Nation, What We Learned: Two Generations Reflect on Tsimshian Education and the Day Schools (Vancouver: UBC Press, 2016).

18 Paul Hackett, Sylvia Abonyi, and Roland F. Dyck, "Anthropometric Indices of First Nations Children and Youth on First Entry to Manitoba/Saskatchewan Residential Schools - 1919 to 1953," International Journal of Circumpolar Health 75 (2016): 1-9, doi. 10.3402/ijch.v75.30734; Ian Mosby, "Nutrition Research and Human Biomedical Experimentation in Aboriginal Communities and Residential Schools, 1942-1952," Social History 46, no. 91 (2013): 145-72; Ian Mosby and Tracey Galloway, "Hunger Was Never Absent': How Residential School Diets Shaped Current Patterns of Diabetes Among Indigenous Peoples in Canada," Canadian Medical Association Journal 189, no. 32 (2017), doi: https://doi.org/10.1503/cmaj.170448; Ian Mosby and Tracey Galloway, "'The Abiding Condition Was Hunger': Assessing the Long-term Biological and Health Effects of Malnutrition and Hunger in Canada's Residential Schools," British Journal of Canadian Studies 30, no. 2 (2017): 147-162.

19 Anthony Di Mascio and Leigh Hortop-Di Mascio, "Residential Schooling in the Arctic: A Historical Case Study and Perspective," Native Studies Review 20, no. 2 (2011): 3149; Heather E. McGregor, "Listening for More (Hi)Stories from the Arctic's Dispersed and Diverse Educational Past," Historical Studies in Education 27, no. 1 (2015): 19-39.

20 Jo-Ann Episkenew, Taking Back Our Spirits: Indigenous Literature, Public Policy, and Healing (Winnipeg: University of Manitoba Press, 2009), 75.

21 Rita Joe, Song of Eskasoni: More Poems of Rita Joe (Charlottetown, PEI: Ragweed, 1988); Shirley Sterling, My Name Is Seepeetza (Vancouver: Douglas \& McIntyre, 1992); Tomson Highway, Kiss of the Fur Queen (Toronto: Doubleday Canada, 1998); Nicola I. Campbell and Kim LaFave, Shi-Shi-Etko (Toronto: Groundwood Books, 2005); Oskiniko Larry Loyie, Connie Brissenden, and Heather D. Holmlund, As Long as the Rivers Flow (Toronto: Groundwood, 2005); Nicola I. Campbell, Shin-Chi's Canoe (Toronto: Groundwood, 2008); Robert Arthur Alexie, Porcupines and China Dolls (Penticton, BC: Theytus Books, 2009); Margaret Pokiak-Fenton and Christy JordanFenton, Fatty Legs: A True Story (Toronto: Annick, 2010); Richard Wagamese, Indian Horse (Vancouver: Douglas \& McIntyre, 2012); Drew Hayden Taylor, God and the Indian: A Play (Vancouver: Talonbooks, 2014); David Alexander Robertson and Julie Flett, When We Were Young (Winnipeg: Highwater Press, 2016).

22 Sam McKegney, Magic Weapons: Aboriginal Writers Remaking Community after Residential School (Winnipeg: University of Manitoba Press, 2007), 7.

23 Basil Johnston, Indian School Days (Toronto: Key Porter Books, 1988).

24 Basil Johnston and Sam McKegney, "Foreword," in Magic Weapons: Aboriginal Writers Remaking Community after Residential School (Winnipeg: University of Manitoba Press, 2007), vii-xv; Johnston, Indian School Days.

25 Isabelle Knockwood, Out of the Depths: The Experiences of Mi'kmaw Children at the Indian Residential School at Shubenacadie, Nova Scotia (Halifax: Fernwood, 1992, 2015).

26 Theodore Fontaine, Broken Circle: The Dark Legacy of Indian Residential Schools (Surrey, BC: Heritage House, 2010); Bev Sellars, They Called Me Number One: Secrets and Survival at an Indian Residential School (Vancouver: Talonbooks, 2013); Edmund Metatawabin, Up Ghost River (Toronto: Vintage, 2014); Joseph Auguste Merasty, The Education of Augie Merasty (Regina: University of Regina Press, 2015); Arthur Bear Chief, My Decade at Old Sun, My Lifetime of Hell (Athabasca, AB: Athabasca University Press, 2016).

27 See Laura L. Terrance for an elaboration of this distinction: "Resisting Colonial Education: Zitkala-Sa and Native Feminist Archival Refusal," International Journal of Qualitative Studies in Education 24, no. 5 (2011): 621-26. 
28 Truth and Reconciliation Commission of Canada, "Honouring the Truth, Reconciling for the Future: Summary of the Final Report of the Truth and Reconciliation Commission of Canada," 2015, 29; Tim Alamenciak, "Court Orders Residential School Documents Destroyed - After 15 Years," Toronto Star, August 7, 2014. See also J. J. Ghaddar, "The Spectre in the Archive: Truth, Reconciliation, and Indigenous Archival Memory," Archivaria 82 (2016): 3-26.

29 See Shoshana Felman, Testimony: Crises of Witnessing in Literature, Psychoanalysis, and History (New York: Routledge, 1991); Susan Sontag, Regarding the Pain of Others (New York: Picador, 2003); Roger I. Simon, The Touch of the Past: Remembrance, Learning, and Ethics (New York: Palgrave Macmillan, 2005); Claudia Eppert, "Relearning Questions: Responding to the Ethical Address of Past and Present Others," in Between Hope and Despair: Pedagogy and the Remembrance of Historical Trauma, ed. Roger I. Simon, Sharon Rosenberg, and Claudia Eppert (Lanham, MD: Rowman \& Littlefield, 2000), 213-30; Sara Ahmed, The Cultural Politics of Emotion (New York: Routledge, 2004).

30 See Glen Coulthard, Red Skin, White Masks: Rejecting the Colonial Politics of Recognition, Indigenous Americas (Minneapolis: University of Minnesota Press, 2014); Sheryl Lightfoot, "Settler State Apologies to Indigenous Peoples: A Normative Framework and Comparative Assessment," Native American and Indigenous Studies 2 (2015): 15-39; Jeff Corntassel and Cindy Holder, "Who's Sorry Now? Government Apologies, Truth Commissions, and Indigenous Self-Determination in Australia, Canada, Guatemala, and Peru," Human Rights Review 9, no. 4 (2008): 465-89.

31 Jennifer Henderson and Pauline Wakeham, eds., Reconciling Canada: Critical Perspectives on the Culture of Redress (Toronto: University of Toronto Press, 2013); Ronald Niezen, Truth and Indignation: Canada's Truth and Reconciliation Commission on Indian Residential Schools, Teaching Culture: UTP Ethnographies for the Classroom (Toronto: University of Toronto Press, 2013); Paulette Regan, Unsettling the Settler Within: Indian Residential Schools, Truth Telling, and Reconciliation in Canada (Vancouver: UBC Press, 2010); Arthur Manuel, Unsettling Canada: A National Wake-up Call (Toronto: Between the Lines, 2015).

32 Patrick Wolfe, Settler Colonialism and the Transformation of Anthropology: The Politics and Poetics of an Ethnographic Event (London: Cassell, 1999).

33 Lorenzo Veracini, Settler Colonialism: A Theoretical Overview, Cambridge Imperial and Post-Colonial Studies Series (London: Palgrave Macmillan, 2010); Audra Simpson, Mohawk Interruptus: Political Life Across the Borders of Settler States (Durham, NC: Duke University Press, 2014); Mishuana Goeman, "Disrupting a Settler-Colonial Grammar of Place: The Visual Memoir of Hulleah Tsinhnahjinnie," in Theorizing Native Studies, ed. Audra Simpson and Andrea Smith (Durham, NC: Duke University Press, 2014), 235-265.

34 Eva Mackey, The House of Difference: Cultural Politics and National Identity in Canada (London: Routledge, 1999), 12.

35 Corey Snelgrove, Rita Kaur Dhamoon, and Jeff Corntassel, "Unsettling Settler Colonialism: The Discourse and Politics of Settlers, and Solidarity with Indigenous Nations," Decolonization: Indigeneity, Education \& Society 3, no. 2 (2014): 4; Eve Tuck and K. Wayne Yang, "Decolonization Is Not a Metaphor," Decolonization: Indigeneity, Education \& Society 1, no. 1 (2012): 1-40.

36 Woolford, This Benevolent Experiment, 31-32.

37 Andrew Woolford, Jeff Benvenuto, and Alexander Hinton, eds., Colonial Genocide in Indigenous North America (Durham, NC: Duke University Press, 2014).

38 Jane Griffith, "One Little, Two Little, Three Canadians: The Indians of Canada Pavilion and Public Pedagogy, Expo 1967," Journal of Canadian Studies 49, no. 2 (2015): 171-204. 
39 Alanis Obomsawin, Christmas at Moose Factory, National Film Board of Canada, 1971.

40 Milloy, A National Crime, 195, 208.

41 Ibid., 202, 234.

42 Michelle Pidgeon, Marissa Muñoz, and Jo-ann Archibald, "Indian Control of Indian Education: Reflections and Envisioning the Next 40 Years," Canadian Journal of Native Education 36, no. 1 (2013): 5-35.

43 Brian John Low, NFB Kids: Portrayals of Children by the National Film Board of Canada 1939-89 (Waterloo, ON: Wilfrid Laurier University Press, 2002).

44 Welsh, Kuper Island: Return to the Healing Circle; Terrance Houle, Cows, V-Tape, 2003; Lisa Jackson, Suckerfish, V-Tape, 2004; Nadia McLaren, Muffins for Granny, Mongrel Media, 2007; Shelley Niro, Robert's Paintings, V-Tape, 2011; Douglas Keesic and Lena Recollet, Historical Landmark, V-Tape, 2011; Shane Belcourt, A Common Experience, The Breath Films, 2013; Jeff Barnaby, Rhymes for Young Ghouls, Les Films Séville, 2013; Kent Monkman, Sisters \& Brothers, National Film Board of Canada, 2015.

45 Michelle Bellefontaine, "Wildrose Constituency President Criticized for Comparing GSAs to Residential Schools," CBC News, April 11, 2017, http://www.cbc.ca/news/ canada/edmonton/wildrose-gsas-residential-schools-1.4066382.

46 Allison Jones, "Tory Leadership Hopeful Compares Ontario Sex Ed to Residential Schools," Globe and Mail, September 21, 2016, https://www.theglobeandmail.com/ news/national/parents-protest-sex-ed-curriculum-direct-some-ire-at-patrick-brown/ article31988441/.

47 National Film Board of Canada, "Indigenous Action Plan," http://onf-nfb.gc.ca/en/ indigenous-action-plan/.

48 Dylan Robinson and Keavy Martin, eds., Arts of Engagement: Taking Aesthetic Action in and Beyond The Truth and Reconciliation Commission of Canada, Indigenous Studies Series (Waterloo, ON: Wilfrid Laurier University Press, 2016), 3. 